showed the character of the infection to be of varying type. His paper also slows that the point of infection is not the same in cvery case. It is interesting that in two or three of the cases the teeth proved to be the infecting point, and the question suggests itself, was it the injection of the cocaine by the dentist, or was it the pulling of the tecth which caused the inflammation to start up? In a case which Dr. Davis reported a lawsuit was thrcatened to prosecute the dentist for introducing the infection, whereas it is very well known that dentists, as a rule, object very seriously to pulling tecth or doing any operative procedures on the mouth when there is a marked inflammation of the structures.

Mention was made by Dr. Price of the lymphatics, and Dr. Thomas likewise referred to the lmpliatics carrying the infection from the centre or interior of the month to the ontside of the jaw in the submaxillary region. Dr. Davis has nover thought that the infection was transmitted primarily by the lymplatics. However, in one of his cases Dr. Price mentioned that some of the lymplatics were involved. This is the first case in which Dr. Davis lias ever heard of involvement of the lymplatics, as such, being recognized. In other words, although we have lymphatics in profission along the deep vessels of the neck, yet we do not find isolated enlargement of lymplatic nodes, but we do find inflammation spreading along the cellular tissuc.

Dr. Davis thought particular attention should be called to the treatment in the cases reported. He thinks their prompt recovery was due to the vigorous treatment which they received. The appcarance of a patient with this condition is rcally alarming, and when these cases fall into the liands of general practitioners who are not proficient in scverc surgical procclurcs, they arc afraid to make such incisions as are clemanded in such cases. The extent of the incisions demanded was well shown in some of Dr. Price's cases, in which le made an incision into the month from the outside in the median line, and likewise incisions on both sides in the submaxillary region.

\title{
THE CONSERVATIVE TREATMENT OF FRACTURES OF THE FEMUR.
}

Dr. A. P. C. Asminurst read a paper entitled End-Results of Fractures of the Femur Treated Conservatively, for which see page 748 . 
Dr. Richard H. HARTE said he could not understand why so many surgeons, instead of sticking to old and tried methods of procedure always wanted to try something elsc just because it was new. He really thinks it remarkable that in fractures of the tligh the results are so good, for he thinks this bonc, above all others, is badly treated. Everyone seems to think that in order to treat a fracture of the thigh all that is ncccssary is to hang on to the lieel 6 or 8 pounds of weiglits, paying no attention to the extension of the leg or the relative position of the sand-bags to the leg.

He thinks Dr. Jolın Aslihurst is the surgeon to whom the greatest thanks are due for the conservative treatment of fractures of the thigl. To obviate the use of sand-bags he reverted to the use of the old-fashioned Dupuytren's splint in conjunction with bran-bags and weights.

Dr. Harte cloes not recall a single case of unumited fracture of the thigh in his experience. In cases where there are multiple fractures, great allowance should be made, as Nature is only capable of repairing a certain nuuber of fractures at a time. Very often the larger bone is the one which will be the slowest to unite.

Dr. G. G. Davis said he thonght the results in these cases rather surprising. When it comes to fractures bclow the neck we rather expect unfavorable results, but here in 21 cases of the neck we find 5 cases with apparently perfect functional results; 8 with no disability but a limp; 6 with marked impairment of funetion; and only 2 ineapacitated. It is not infrequent for patients with intracapsular fractures to take to their beds and remain there until they die. Dr. Davis thought if the impairment of function in the 6 cases mentioned even allowed the patients to get around at all, that the results were surprisingly good, partienlarly when it is remembcred that in these cases there were varions forms of treatment. He unclerstood that some of the methods pursued were not the so-called modern methods of abduetion or lateral traction, but were simply the employment of the ordinary Buek's extension.

Dr. A. P. C. Asmmurst, in elosing, said that of the 5 patients with fraeture of the neek of the femur who reeovered without functional impairment, two were elildren; one was a man 70 years of age. When this latter patient eame baek to the hospital 
with no impairment whatever, it was necessary to look up his history, whieh showed that the diagnosis had been eonfirmed by a skiagraph, to convince the examiners that he had really sustained a fracture of the neek of the femur. Dr. Ashhurst adeled that Dr. Newell and he agreed entirely with Dr. Harte that the question of shortening was of secondary importance, since, as Dr. Harte saicl, it was of course impossible to know what had been the length of the fractured limb before the aceident. He thought, however, if a patient had been so unfortunate as to have one leg an inch or more longer than its fellow, he would have to be congratulated should the result of his fracture enable him to be discharged with two legs of equal length.

\section{GERSUNY'S OPERATION FOR THE CURE OF ENURESIS.}

Dr. Givilyat G. Davis presented a young girl, aged I 5 years, who was admitted to lospital under his care with the following history: She had liad most all of the diseases of childhood besides typhoid fever. Menstruation began at the age of 12, and she stated that slie did not menstruate from the vagina but at each monthly period had considerable bleeding from the nose accompanied by lieadache. A year and a half previously she passed tlirough an attack of typlooid fever at another hospital. She has always been of a nervous disposition and a year ago began to lave nocturnal incontinence of uriue. She passed urine involuntarily five to seven times each night. She was under treatment for the trouble in the medical ward and was afterwards operated on for appendieitis three montlis previons to her present operation.

Urine: Sp. gr., I020, acid, no albumin nor sugar; few epithelial eells; no urethral polypus or other abnormal conditions.

She was etherized and the uretlura surrounded by a circular ineision and loosened from its surronndings. It was then tivisted three-fourths of a turn on its longitndinal axis until a feeling of resistance was experienced, the margin was then sewn to the adjacent tissues by interrupted sutures of fine elromic gut. A catheter was inserted and retaince for two or three days. Primary union occurred and sle was soon discliarged from the hospital eured.

The proeedure used in this ease was that devised by Gersuny (Centralblatt fïr Chirurgie, I888) and is similar to his well-known opcration for incontinence of feces (Centralblatt für 